\title{
ERRATUM
}

\section{Pseudomonas pseudoalcaligenes subsp. citrulli subsp. nov.}

N. W. SCHAAD, G. SOWELL, JR., R. W. GOTH, R. R. COLWELL, AND R. W. WEBB

Department of Plant Pathology; University of Georgia, Georgia Experiment Station, Experiment, Georgia 30212; Agricultural Research Service, Georgia Experiment Station, Experiment, Georgia 30212;

Agricultural Research Service, P G G I, Beltsville, Maryland 29705; and Department of Microbiology, University of Maryland, College Park, Maryland 20747

Volume 28 , no. 1 , p. 117 , address line 1: The first address was incorrect as originally printed; it is correct as given above.

Page 117, column 1, line 3 of Materials and Methods: Insert "C-42" between "Strains" and " $\mathrm{C}$ 43."

Page 120, Table 2: Oxidation production for P. avenae should read “-_."

Page 122, column 2, line 4: Insert " $P$. avenae should be included in group III also. However," between "opinion" and "P. avenae."

Page 124, column 2, line 2 of Reprint Requests: Should read “... Pathology, University of Georgia, Georgia Experiment Station ...." 